\title{
The Correlation between Apolipoprotein B Level and Inflammatory Markers in Obese
}

\author{
Dian Anindita Lubis ${ }^{1}$, Dharma Lindarto ${ }^{2 *}$ \\ ${ }^{1,2}$ Department of Internal Medicine, Faculty of Medicine, Universitas Sumatera Utara
}

\begin{abstract}
Apolipoprotein B (ApoB) levels reflect the total number potentially atherogenic particles that can predict cardiovascular risk. The purpose of this study was to assess if the ApoB in obese subjects is associated with inflammatory markers. This cross-sectional study was conducted on 80 obese patients at $\mathrm{H}$. Adam Malik Hospital, Medan, Indonesia. Results: Of the 80 patients studied, the average age was $38.95+8.13$ years old. There was a strong positive correlation between $\mathrm{ApoB}$ and triglycerides $(\mathrm{r}=0.44, \mathrm{p}<0.001)$, low-density lipoprotein cholesterol $(r=0.74, p<0.001)$, and HOMA-IR $(r=0.31, p=0.005)$, however not with the inflammatory markers; adiponectin $(\mathrm{r}=-0.23, \mathrm{p}=0.41)$ and Chemerin $(\mathrm{r}=0.021$, $\mathrm{p}=0.851$ ). In obesity, ApoB significantly associated with lipid and insulin resistance, as a risk factor for cardiovascular disease.
\end{abstract}

Keyword: Apolipoprotein B, Obesity, Cardiovascular Disease, Atherosclerosis

Abstrak. Kadar Apolipoprotein B (ApoB) mencerminkan jumlah total partikel aterogenik potensial yang dapat memprediksi risiko kardiovaskular. Tujuan dari penelitian ini adalah untuk menilai apakah APoB pada subjek obesitas dikaitkan dengan penanda inflamasi. Penelitian cross-sectional ini dilakukan pada 80 pasien obesitas di Rumah Sakit H. Adam Malik, Medan, Indonesia. Hasil: Dari 80 pasien yang diteliti, usia rata-rata adalah 38,95 $+8,13$ tahun. Ada korelasi positif yang kuat antara ApoB dan trigliserida $(r=0,44, p$ $<0,001)$, kolesterol lipoprotein densitas rendah $(r=0,74, p<0,001)$, dan HOMA-IR $(r=$ $0,31, p=0,005)$, namun tidak dengan penanda inflamasi; adiponectin $(r=-0,23, p=0,41)$ dan Chemerin $(r=0,021, p=0,851)$. Pada obesitas, ApoB secara signifikan terkait dengan resistensi lipid dan insulin, sebagai faktor risiko penyakit kardiovaskular.

Kata Kunci: Apolipoprotein B, Obesitas, Penyakit Kardiovaskular, Aterosklerosis

Received [date month year] | Revised [date month year] | Accepted [xx Month xxxx]

\section{Introduction}

Obesity is the accumulation of excess abnormal fat that may interfere in an optimal state of health. It has long been associated with an increased risk of mortality from any cause, predominantly through chronic diseases, such as cardiovascular disease, type 2 diabetes, and cancer [1]. The increment of cardiovascular disease risk is through inflammation, hyperlipidemia, elevated blood glucose, elevated insulin levels and high blood pressure [2], [3].

\footnotetext{
${ }^{*}$ Corresponding author at: Faculty of Medicine, Universitas Sumatera Utara, H. Adam Malik Hospital, Jalan Bunga Lau No 17, Medan 20136, Indonesia

E-mail address: dharma@usu.ac.id
} 
In obese subjects, the risk for atherosclerotic disease is still high even after adjustment for established risk factors. It is thought that there are abnormalities in lipoprotein metabolism that do not produce hyperlipidemia and yet accelerate atherosclerosis [4]. Low-density lipoprotein (LDL) are atherogenic; however, when triglyceride concentration is high, LDL values are often not available. Therefore, other markers of lipoprotein-related to cardiovascular disease are needed. The measurement of lipoprotein particle, apolipoprotein B (ApoB), may improve the prediction of the risk of cardiovascular disease [5], [6].

As part of metabolic syndrome, chronic inflammation was also been associated with obesity. Larger adipocytes in abdominal obesity alter the ability to suppress lipolysis. Fat tissue releases classical adipocytokines (adiponectin, leptin, resistin) and new adipocytokines (chemerin, vaspin, omentin) that have a role in insulin resistance and increased cardiovascular risk [7], [8].

Several studies examined the association between plasma lipid and inflammatory markers. However, the evaluation of $A p o B$ is rarely included. Therefore, we aim to examine the association between ApoB and inflammatory markers in obesity.

\section{Materials and Methods}

This cross-sectional study was held in H. Adam Malik Hospital, Medan, Indonesia. Obese nurses $($ BMI $>25 \mathrm{~kg} / \mathrm{m} 2)$ age 30-55 were recruited. Eighty subjects agreed to participate. Informed consent was obtained from each subject, following approval of the local Ethical Committee. Subjects with secondary illness or obesity such as acute inflammation, anemia, menopause, diabetes, pregnancy, cardiovascular disease, chronic kidney disease, liver dysfunction, smoked, consumed corticosteroid, estrogen, beta-adrenergic receptor agonists, nitrates, or other vasodilator agents were excluded.

Blood samples were collected from the subjects in the morning after 10-12 hours of fasting combined with ethylenediaminetetraacetate (EDTA) containing heparin, then centrifuged.

\subsection{Biochemical analysis}

Serum HDL cholesterol (HDL-C), and triglycerides (TG) were analyzed by the enzymatic colorimetric method while Apo-B levels were assessed by the immunoassay method with Hitachi Modular analyzer using the Roche Diagnostic kit. Insulin levels were determined by the chemiluminescence immunoassay method using the DPC Immulite-I analyzer (Diagnostic Products Corp, Los Angeles, CA, USA) kit.

HOMA-IR formula $=[($ fasting glucose serum $(\mathrm{mmol} / 1) \times$ fasting insulin $(\mu \mathrm{U} / \mathrm{ml}) / 22,5]$ was used to determine the index of insulin resistance [9].

\subsection{Statistical analysis}


Data are presented as mean + standard deviation. All data were summarized as descriptive statistics. To determine whether a variable was normally distributed, we used the Shapiro-Wilk test. The parametric analysis was performed on variables with normal distribution, whereas the nonparametric test was performed on variables with the abnormal distribution. Furthermore, the Pearson and Spearman test were used to evaluate the correlation between variables according to the variable distribution. $\mathrm{P}<0.05$ was accepted as an indication of statistical significance. SPSS for Windows was used for the statistical analysis.

\section{Results}

This analysis included 80 obese subjects with no previous history of cardiovascular disease. The average age was $38.95+8.13$ years. The traditional risk factors for cardiovascular disease, as well as inflammatory markers measured in this study, are presented in Table 1.

Pearson correlation of apoB with all traditional risk factors is presented in Table 2. In general, apoB correlated positively with LDL-C, TG, HOMA-IR and negatively with HDL-C. ApoB also has a strong correlation with HOMA-IR. However, there is no correlation between apoB and inflammatory markers.

Table 1 Baseline Characteristic of Obesity Subjects

\begin{tabular}{llc}
\hline \multicolumn{2}{c}{ Parameters } & Total $(\mathbf{m e a n} \pm \mathbf{S D}) ; \mathbf{n}=\mathbf{8 0}$ \\
Age & $($ years $)$ & $38.95 \pm 8.13$ \\
\hline Body weight & $(\mathrm{Kg})$ & $75.35 \pm 13.49$ \\
WC & $(\mathrm{cm})$ & $91.95 \pm 9.59$ \\
LDL-C & $(\mathrm{mg} / \mathrm{dL})$ & $138.12 \pm 32,40$ \\
HDL-C & $(\mathrm{mg} / \mathrm{dL})$ & $53.72 \pm 16.73$ \\
TG & $(\mathrm{mg} / \mathrm{dL})$ & $131.30 \pm 75.92$ \\
Adiponectin & & $4.42 \pm 2.40$ \\
Chemerin & $(\mathrm{ng} / \mathrm{mL})$ & $408.64 \pm 118.41$ \\
ApoB & $(\mathrm{g} / \mathrm{L})$ & $98 . .43 \pm 20.27$ \\
HOMA-IR & & $2.36 \pm 3.02$ \\
\hline
\end{tabular}

Abbreviations: WC, waist circumference; HOMA-IR: homeostasis model assessment of insulin resistance;; LDL-C, low density lipoprotein cholesterol; HDL-C, high density lipoprotein cholesterol; TG, triglycerides; ApoB: apolipoprotein B. 
Table 2 Relationship Between ApoB and Inflammation Markers in Obesity

\begin{tabular}{llcc}
\hline \multicolumn{2}{c}{ Parameter } & r & P \\
\hline Age & $($ year $)$ & 0.209 & 0.063 \\
Body weight & $(\mathrm{Kg})$ & 0.90 & 0.420 \\
WC & $(\mathrm{cm})$ & 0.173 & 0.124 \\
LDL-C & $(\mathrm{mg} / \mathrm{dl})$ & 0.74 & $0.000^{* *}$ \\
HDL-C & $(\mathrm{mg} / \mathrm{dl})$ & -0.33 & $0.001^{* *}$ \\
TG & $(\mathrm{mg} / \mathrm{dl})$ & 0.44 & $0.000^{* *}$ \\
HOMA-IR & & 0.31 & $0.005^{* *}$ \\
Adiponectin & & -0.23 & 0.410 \\
Chemerin & $(\mathrm{ng} / \mathrm{dl})$ & 0.021 & 0.851 \\
\hline
\end{tabular}

Abbreviations: BMI, body mass index; WC, waist circumference; HOMA-IR: homeostasis model assessment of insulin resistance; LDL-C, low density lipoprotein cholesterol; HDL-C, high density lipoprotein cholesterol; TG, triglycerides; ApoB: apolipoprotein B.

$* P<0.05, * * P<0.01$

\section{Discussion}

This study demonstrated that in obese subjects, plasma ApoB is positively correlated with several traditional risk factor for cardiovascular disease and type 2 diabetes (insulin resistance, LDL-C, and TG).

ApoB is a better atherogenic parameter, compare to traditional lipid parameter (LDL-C and TG), because ApoB levels reflect the number of atherogenic lipoprotein particles, such as VLDL, LDL, and intermediate-density lipoprotein. One cross-sectional study examined the correlation of $\mathrm{ApoB}$ and risk of coronary heart disease $(n=13,523)$, ApoB was found to be independently related to the risk of CHD using Framingham risk score (FRS) [10]. Moreover, the elevation of ApoB levels is also found in normolipidemic patients with the early coronary arterial disease even when total and LDL-C levels are normal [11].

Insulin resistance, measured with the homeostasis index (HOMA-IR), correlated with apoB in this study supports the association of insulin resistance with lipoprotein transport. The results of the present study are in agreement with the previous study on 476 subjects, demonstrating that apoB correlated with insulin resistance (HOMA-IR) [12].

Earlier studies have shown that the increment of plasma ApoB was associated with inflammatory markers (hsTNF- $\alpha$, IL-6, hsCRP, and orosomucoid). Lipoprotein thought to have triggered inflammation in humans. Contradict with our finding, we did not find the correlation between ApoB and inflammatory markers (adiponectin and chemerin). Schlitt et al. also found that ApoB did not correlate with CRP [13]. It could be as a result of the medical treatment that may interfere with the results.

Our study has some limitations. As is the case in cross-sectional studies, the correlative nature of this analysis does not necessarily reflect causality but allows the generation of hypotheses 
regarding plausible mechanisms and the impact of our findings. Future prospective studies should be used to investigate the theories of this study.

\section{Conclusion}

The association between apoB and increased cardiovascular disease risks were related to lipid, and insulin resistance.

\section{REFERENCES}

[1] D. K. Tobias dan F. B. Hu, "The association between BMI and mortality: implications for obesity prevention," Lancet Diabetes Endocrinol., vol. 6, no. 12, hlm. 916-917, 2018.

[2] K. F. Adams $d k k$., "Overweight, obesity, and mortality in a large prospective cohort of persons 50 to 71 years old," N. Engl. J. Med., vol. 355, no. 8, hlm. 763-778, 2006.

[3] B. Klop, J. Elte, dan M. Cabezas, "Dyslipidemia in obesity: mechanisms and potential targets," Nutrients, vol. 5, no. 4, hlm. 1218-1240, 2013.

[4] G. Egusa, W. F. Beltz, S. M. Grundy, dan B. V. Howard, "Influence of obesity on the metabolism of apolipoprotein B in humans.," J. Clin. Invest., vol. 76, no. 2, hlm. 596-603, 1985.

[5] I. Holme, A. T. Høstmark, dan S. A. Anderssen, "ApoB but not LDL-cholesterol is reduced by exercise training in overweight healthy men. Results from the 1-year randomized Oslo Diet and Exercise Study," J. Intern. Med., vol. 262, no. 2, hlm. 235-243, 2007.

[6] M. H. Khadem Ansari, Y. Rasmi, A. Rahimi Pour, dan M. Jafarzadeh, "The association between serum apolipoprotein AI and apolipoprotein B and the severity of angiographical coronary artery disease," Singapore Med. J., vol. 50, no. 6, hlm. 610-613, 2009.

[7] M. S. Ellulu, I. Patimah, H. Khaza'ai, A. Rahmat, dan Y. Abed, "Obesity and inflammation: the linking mechanism and the complications," Arch. Med. Sci. AMS, vol. 13, no. 4, hlm. 851, 2017.

[8] A. Gateva, Y. Assyov, A. Tsakova, dan Z. Kamenov, "Classical (adiponectin, leptin, resistin) and new (chemerin, vaspin, omentin) adipocytokines in patients with prediabetes," Horm. Mol. Biol. Clin. Investig., vol. 34, no. 1, 2018.

[9] D. R. Matthews, J. P. Hosker, A. S. Rudenski, B. A. Naylor, D. F. Treacher, dan R. C. Turner, "Homeostasis model assessment: insulin resistance and $\beta$-cell function from fasting plasma glucose and insulin concentrations in man," Diabetologia, vol. 28, no. 7, hlm. 412-419, 1985.

[10] J.-H. Ryoo, E.-H. Ha, S.-G. Kim, S. Ryu, dan D.-W. Lee, "Apolipoprotein B is highly associated with the risk of coronary heart disease as estimated by the Framingham risk score in healthy Korean men," J. Korean Med. Sci., vol. 26, no. 5, hlm. 631-636, 2011.

[11] F. Dati dan J. Tate, "Reference materials for the standardization of the apolipoproteins AI and B, and lipoprotein (a)," EJIFCC, vol. 13, no. 3, hlm. 73, 2001.

[12] W. Wang, P. Blackett, S. Khan, dan E. Lee, "Apolipoproteins AI, B, and C-III and obesity in young adult cherokee," J. Lipids, vol. 2017, 2017.

[13] A. Schlitt $d k k$., "Prognostic value of lipoproteins and their relation to inflammatory markers among patients with coronary artery disease," Int. J. Cardiol., vol. 102, no. 3, hlm. 477-485, 2005. 